\title{
Flame retardant properties of oil palm trunk particleboard with addition of epoxy resin as a binder and aluminium hydroxide and magnesium hydroxide as additives
}

\author{
MOHANA BASKARAN, ROKIAH HASHIM*, JIN YEN LEONG, YING NI ONG, \\ MOHD FIRDAUS YHAYA and OTHMAN SULAIMAN \\ Division of Bioresource, Paper and Coatings Technology, School of Industrial Technology, Universiti Sains Malaysia, \\ 11800 George Town, Penang, Malaysia \\ *Author for correspondence (hrokiah@usm.my)
}

MS received 8 February 2018; accepted 21 November 2018; published online 29 April 2019

\begin{abstract}
This research aimed at investigating the effect of epoxy resin and flame retardant additives on oil palm trunk particleboard. The oil palm trunk was used as a raw material with epoxy resin as a binder, which was synthesized by a reaction of epichlorohydrin and phenolphthalein, while aluminium hydroxide and magnesium hydroxide were used as flame retardant additives to manufacture particleboards. Four different types of particleboards were produced, control board, board with $10 \%$ epoxy resin, board with $10 \%$ epoxy resin and $6 \%$ aluminium hydroxide and board with $10 \%$ epoxy resin and $6 \%$ magnesium hydroxide, based on a target density of $0.80 \mathrm{~g} \mathrm{~cm}^{-3}$, at a temperature of $180^{\circ} \mathrm{C}$, a pressure of $5 \mathrm{MPa}$ and a pressing time of $20 \mathrm{~min}$. The mechanical, physical, functional group, spectroscopic, morphological and elemental analysis properties were determined in comparison with control particleboard. Thermal degradation and flame retardant analyses were also carried out to analyse the thermal properties of particleboards. The results indicated that particleboard bonded with epoxy resin and flame retardant additives had improved mechanical, physical, thermal and flame retardant properties compared to control oil palm trunk particleboard. Overall results showed that epoxy resin as a binder and aluminium hydroxide and magnesium hydroxide as additives have the potential to be incorporated into the particleboard to improve flame retardant properties.
\end{abstract}

Keywords. Oil palm trunk; epoxy resin; mechanical; physical; flame retardant analysis; thermal degradation.

\section{Introduction}

The oil palm (Elaeis guineensis) is becoming one of the most valuable commercial agricultural crops in Malaysia as it is easily cultivated [1]. Cultivation of oil palm plantation in Malaysia has increased dramatically from years to years due to its oil producing fruits. In Malaysia, an oil palm planted area reached 5.74 million hectares in 2016, which was an increase by about $1.77 \%$ compared to 5.64 million hectares in 2015 [2]. At the same time, the industry generates at least 30 million tons of biomass waste per year in the form of palm kernel, trunks, empty fruit branches and leaves [3]. About $75 \%$ of the solid biomass in the form of fronds and trunks are found in the oil palm plantation and it is estimated that about 85 million tonnes of biomass based on dry weight will be generated by the year 2020 [4].

Oil palm trunks will be only available when the economic life span of palm tree achieves replanting period at an average age of about 25 years. Currently, most of the trunks are retained in the field as fertilizer. They are either chipped or felled to decompose naturally in the plantation. The utilization of oil palm trunks into value added products could be an essential principle of waste management by minimizing and recycling waste materials and also reducing high dependency on wood resources.

Particleboard was successfully developed from oil palm trunk waste by Ahmad et al [5] using urea formaldehyde resin. In general, conventional particleboard was incorporated with formaldehyde based resin to obtain a high end product but inversely it emits toxic gases which are detrimental to human health and also to the environment [6]. This prompted the development of particleboard without addition of any binder or resin which is also known as binderless from oil palm biomass by Hashim et al $[7,8]$.

Apart from that, particleboards manufactured from wood or non-wood have low flammability as a wood or nonwood material is a naturally growing resource which mainly consists of combustible organic carbon compounds [9]. Fire retardant properties are crucial in the particleboard industry to increase its life span. Therefore, the particleboard industry tends to develop safe and effective flame retardant formulations that could also solve formaldehyde emission.

Epoxy resins have widely been used as adhesives, surface coatings, laminates and matrix materials in wood plastic composites, and in electronic, transport and also aerospace 
industries due to their exceptional characteristics such as superior dimensional stability and excellent mechanical properties with high resistance to corrosion, heat and chemicals [10]. However, their flame resistance needs to be improved with addition of additives such as inorganic hydroxides to improve basic properties of non-wood based particleboard for indoor applications. The quantity used must be minimal to ensure the optimum use of the adhesives and their flame resistant function. Previous work has indicated that a range of the low retention level of 5 to $10 \%$ should be enough to treat particleboards for a fire retardant purpose [11].

Therefore, in this research, oil palm trunk particleboard is produced by using epoxy resin which is prepared from the reaction between epichlorohydrin and phenolphthalein, and the flame retardant effect is evaluated by adding aluminium hydroxide and magnesium hydroxide as additives. The performance of the particleboard is analysed in terms of physical properties, mechanical properties, thermal properties, functional groups, morphological properties and also elemental composition.

\section{Materials and methods}

\subsection{Preparation of epoxy resin}

Epoxy resin was prepared based on a study by Mun et al [12]. Phenolphthalein (73.14 g, 0.23 moles), epichlorohydrin (124.88 g, 1.35 moles) and $2 \mathrm{ml}$ of distilled water were stirred and heated until reflux. The solution was cooled until the temperature decreased to $80^{\circ} \mathrm{C}$. Five grams of sodium hydroxide pellets were added slowly to the solution. The reflux process was then continued for further $45 \mathrm{~min}$. After excess epichlorohydrin was removed by vacuum distillation, the solution was cooled and $30 \mathrm{ml}$ of benzene was added. Yellow crystals were precipitated and filtered. The filtrate was further heated at a temperature less than $120^{\circ} \mathrm{C}$. Finally, the epoxy resin was added to an oven at $140^{\circ} \mathrm{C}$ for $3 \mathrm{~h}$ to obtain phenolphthalein based epoxy resin. The reactions between phenolphthalein and epichlorohydrin are illustrated in figure 1.

\subsection{Determination of epoxide equivalent}

The epoxide equivalent was determined to analyse the molecular weight of resin [13]. $1.18 \mathrm{~g}$ of potassium hydroxide and $4.10 \mathrm{~g}$ of potassium hydrogen phthalate were dissolved separately with $100 \mathrm{ml}$ of distilled water. A few drops of the phenolphthalein indicator was added into $10 \mathrm{ml}$ of potassium hydroxide and the mixture was titrated with potassium hydrogen phthalate. Twenty-five millilitres of $37 \%$ hydrochloric acid was dissolved in $100 \mathrm{ml}$ of dimethyl formamide. Ten millilitres of this mixture was titrated with standardized potassium hydroxide. One gram of epoxy resin was dissolved in $50 \mathrm{ml}$ of dimethyl formamide hydrochloride solution. The mixture was refluxed for about $20 \mathrm{~min}$. After this, the mixture was cooled and $10 \mathrm{ml}$ of this mixture was titrated with potassium hydroxide solution.

\subsection{Manufacturing parameters}

Oil palm trunk particles used in this study were supplied by Encore Agricultural Industries Sdn Bhd, Kuala Lumpur. The oil palm trunk particles were ground to obtain oil palm trunk particles of size less than $1 \mathrm{~mm}$. Particleboards measuring $205 \times 205 \times 5 \mathrm{~mm}^{3}$ with a target density of $800 \mathrm{~kg} \mathrm{~m}^{-3}$ were manufactured using a hot press machine. Control particleboards were manufactured without addition of epoxy resin and inorganic hydroxides. A 10\% epoxy resin based on oven dry weight of oil palm particles was used for the epoxy resin added particleboard designated as $10 \%$ epoxy resin. A $10 \%$ epoxy resin and $6 \%$ of inorganic hydroxides, namely aluminium hydroxide and magnesium hydroxide, based on oven dry weight of oil palm particles were added as a function of fire retardant additives for flame retardant epoxy resin added particleboard which are categorized as $10 \%$ epoxy resin $+6 \% \mathrm{Al}(\mathrm{OH})_{3}$ and $10 \%$ epoxy resin $+6 \% \mathrm{Mg}(\mathrm{OH})_{2}$.

After blending, mats were manually formed in a mould prior to hot pressing. Particleboards were pressed at a platen temperature of $180^{\circ} \mathrm{C}$. The pressing time was $20 \mathrm{~min}$ and pressing pressure was $5 \mathrm{MPa}$ [14]. A total of 24 particleboards were manufactured with 6 replicates for each type. Particleboards were conditioned at $20^{\circ} \mathrm{C}$ and $65 \%$ relative humidity

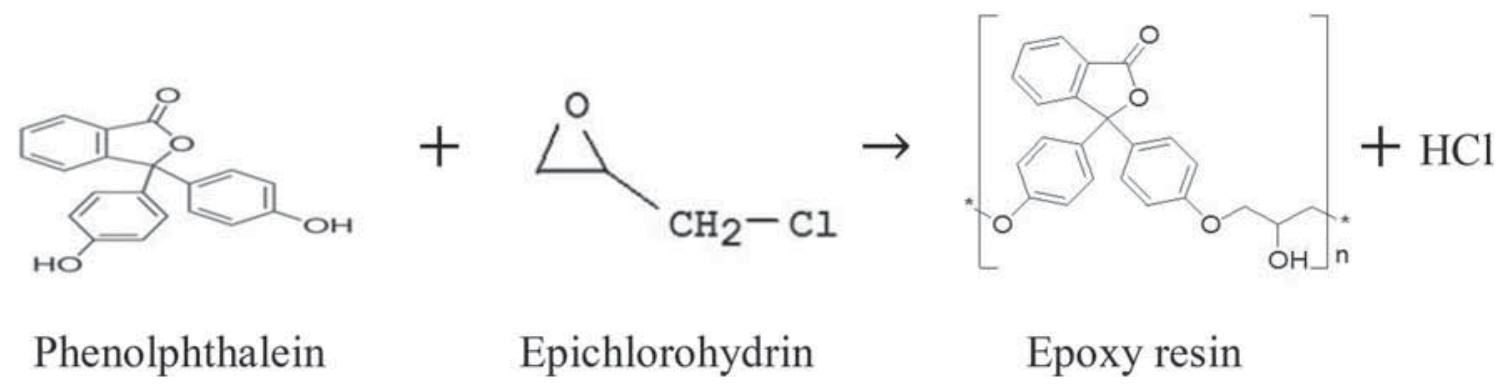

Figure 1. Reaction of phenolphthalein and epichlorohydrin [12]. 
until equilibrium was obtained with moisture content prior to testing.

\subsection{Mechanical and physical properties}

Samples for mechanical and physical properties testing were prepared according to Japanese Industrial Standards A 5908 for particleboard [15]. The modulus of rupture was obtained from an average of two $210 \times 50 \mathrm{~mm}^{2}$ samples for each type of particleboard. The internal bond strength was obtained from an average of three $50 \times 50 \mathrm{~mm}^{2}$ samples for each of particleboard. Thickness swelling after soaking the samples in water for $24 \mathrm{~h}$ was obtained from an average of three $50 \times 50 \mathrm{~mm}^{2}$ samples for each particleboard.

\subsection{Flame retardant and thermal properties}

Flame retardant properties were measured using a limited oxygen index according to British Standard 2782:141 for the determination of flammability by oxygen index [16]. The limited oxygen index was obtained from an average of three $80 \times 10 \mathrm{~mm}^{2}$ samples for each particleboard. Thermal properties were analysed using a Perkin Elmer TGA 7 thermogravimetric analyser. Scans were recorded from 30 to $800^{\circ} \mathrm{C}$ for samples in a powder form of 5-10 $\mathrm{mg}$ placed in an aluminium pan with a heating rate of $20^{\circ} \mathrm{C} \mathrm{min}-1$ under a nitrogen atmosphere.

\subsection{Functional group, crystallinity, morphology and elemental composition properties}

The functional group was determined using a Nicolet Avatar 360 ESP Fourier transform infrared spectrophotometer. The samples in the powder form were analysed between wave numbers of 4000 and $470 \mathrm{~cm}^{-1}$ with a resolution of $4 \mathrm{~cm}^{-1}$ to detect the functional groups of the compounds of each material. The crystalline index was measured using a high resolution $(\mathrm{Hr}) \mathrm{X}$-ray diffractometer (PANalytical $\mathrm{X}^{\prime}$ Pert Pro MRD). A $2 \theta$ angle ranging from $10^{\circ}$ to $40^{\circ}$ in a reflection mode was scanned at $2^{\circ} \mathrm{min}^{-1}$. The morphology and elemental composition were analysed using a scanning electron microscope with energy dispersive Xray analysis (LEO Supra $50 \mathrm{Vp}$ ), Field Emission SEM, (Carl-Zeiss SMT, Oberkochen, Germany). Micrographs were obtained from cross sections of $5 \times 5 \mathrm{~mm}^{2}$ for each type of particleboard.

\section{Results and discussion}

\subsection{Epoxide equivalent of epoxy resin}

Epoxide equivalent weight is the characteristic that determines resin solubility, which is defined as the weight of resin in grams which contains $1 \mathrm{~g}$ of equivalent [17]. Thus, the determination of epoxy equivalent is to determine the molecular weight of resin produced. The average molecular weight of epoxy resin produced is $2856.72 \mathrm{~g} \mathrm{~mol}^{-1}$.

\subsection{Evaluation of mechanical and physical properties}

The results of mechanical properties, modulus of rupture and internal bond strength, physical properties and thickness swelling of particleboards manufactured from oil palm trunk particles were evaluated by Tukey's test as presented in table 1. It demonstrated the influence of addition of epoxy resin as a function of resin and aluminium hydroxide and magnesium hydroxide as a function of flame retardant additives on the mechanical and physical properties of oil palm trunk particleboards to reveal significant differences between responses analysed and the difference was considered significant at $p<0.05$. Four types of oil palm particleboards were manufactured; control particleboard, particleboard with $10 \%$ of epoxy resin (10\% epoxy resin), particleboard with $10 \%$ of epoxy resin and $6 \%$ of aluminium hydroxide $(10 \%$ epoxy resin $\left.+6 \% \mathrm{Al}(\mathrm{OH})_{3}\right)$ and particleboard with $10 \%$ of epoxy resin and $6 \%$ of magnesium hydroxide (10\% epoxy resin $\left.+6 \% \mathrm{Mg}(\mathrm{OH})_{2}\right)$.

All the oil palm trunk particleboards satisfied the minimum requirement of modulus of rupture which is $8 \mathrm{MPa}$, except for control particleboard, and internal bond strength which is $0.15 \mathrm{MPa}$ based on Japanese Industrial Standard for Type 8 particleboard [15].

Tukey's test results show that there are significant interactions between additions of epoxy resin and also flame retardant additives on mechanical properties as observed in table 1. Epoxy resin added particleboard exhibited the highest values of mechanical properties namely modulus of rupture

Table 1. Mechanical and physical properties of oil palm trunk particleboard with Tukey's test result.

\begin{tabular}{lcccc}
\hline Types of boards & Density $\left(\mathrm{g} \mathrm{cm}^{-3}\right)$ & $\begin{array}{c}\text { Modulus of rupture } \\
(\mathrm{MPa})\end{array}$ & $\begin{array}{c}\text { Internal bond strength } \\
(\mathrm{MPa})\end{array}$ & $\begin{array}{c}\text { Thickness swelling }(\%) \\
\text { Control }\end{array}$ \\
$10 \%$ epoxy resin & $0.80(0.15)$ & $5.58(1.61)^{\mathrm{a}}$ & $2.37(1.22)^{\mathrm{a}}$ & $64.42(2.76)^{\mathrm{c}}$ \\
$10 \%$ epoxy resin $+6 \% \mathrm{Al}(\mathrm{OH})_{3}$ & $0.80(0.14)$ & $12.48(1.73)^{\mathrm{c}}$ & $8.14(1.82)^{\mathrm{c}}$ & $47.81(2.34)^{\mathrm{a}}$ \\
$10 \%$ epoxy resin $+6 \% \mathrm{Mg}(\mathrm{OH})_{2}$ & $0.80(0.13)$ & $8.03(1.57)^{\mathrm{b}}$ & $6.41(1.31)^{\mathrm{b}, \mathrm{c}}$ & $54.31(2.35)^{\mathrm{b}}$ \\
\hline
\end{tabular}

Values in parentheses are standard deviation.

Note: Different letters in superscript represent statistical significance while same letters indicate a similarity of differences $(p<0.05)$. 
and internal bond strength. In comparison with control board, modulus of rupture and internal bond strength values of the epoxy resin added particleboard increased significantly with 55.29 and $70.88 \%$, respectively, because epoxy resin has superior mechanical properties and can provide high strength properties to the board [10]. However, mechanical properties decreased significantly with addition of inorganic hydroxides. Modulus of rupture values decreased $35.66 \%$ for addition of $6 \% \mathrm{Al}(\mathrm{OH})_{3}$ and $26.44 \%$ for addition of $\mathrm{Mg}(\mathrm{OH})_{3}$ while internal bond strength values decreased $21.25 \%$ for addition of $6 \% \mathrm{Al}(\mathrm{OH})_{3}$ and $30.84 \%$ for addition of $\mathrm{Mg}(\mathrm{OH})_{3}$. This might be due to the degradation of cellulose by the flame retardant additives [18] that cause poor fibre-matrix interface bonding.

Thickness swelling of oil palm trunk particleboards after $24 \mathrm{~h}$ immersion results in a significant interaction between additions of epoxy resin and flame retardant additives and values are presented in table 1 . The particleboard with $10 \%$ of epoxy resin had the lowest thickness swelling values. The thickness swelling values decreased significantly $25.78 \%$ with addition of $10 \%$ epoxy resin compared to control board because the high resin content in a board can reduce efficiency to absorb moisture or water [19]. However, thickness swelling values increased on addition of flame retardant additives with 11.97 and $14.81 \%$ of $\mathrm{Al}(\mathrm{OH})_{3}$ and $\mathrm{Mg}(\mathrm{OH})_{3}$, respectively, as illustrated in table 1 . The thickness swelling properties of a board is highly dependent on bonding quality [20] and adhesive content. This indicates that the presence of flame retardant additives interrupts the bonding between epoxy resin and fibres. Thus, water easily penetrates into weakly bonded particleboard [21] in comparison with well bonded epoxy resin added particleboard.

\subsection{Evaluation of flame retardant properties}

A limited oxygen index value is a semi-qualitative indicator to measure the effectiveness of flame retardant properties, and thus it should be more than 26 in order to satisfy the need of being self-extinguishing [22]. Based on table 2, epoxy resin added particleboards with flame retardant additives showed high limited oxygen index values which are greater than 26 compared to control and particleboard with epoxy resin. When particleboard with epoxy resin and inorganic hydroxides was exposed to flame combustion, inorganic hydroxides decomposed into water to form a barrier and make

Table 2. Limited oxygen index of oil palm trunk particleboards.

\begin{tabular}{lc}
\hline Types of boards & Limited oxygen index $(\%)$ \\
\hline Control & $24.45(0.15)$ \\
$10 \%$ epoxy resin & $25.25(0.14)$ \\
$10 \%$ epoxy resin $+6 \% \mathrm{Al}(\mathrm{OH})_{3}$ & $28.55(0.16)$ \\
$10 \%$ epoxy resin $+6 \% \mathrm{Mg}(\mathrm{OH})_{2}$ & $27.95(0.15)$ \\
\hline
\end{tabular}

Values in parentheses are standard deviation. the combustion process harder and eventually, more oxygen was needed to propagate combustion [23]. This exhibits that both inorganic hydroxides are highly potential flame retardant additives.

\subsection{Evaluation of thermal properties}

The influences of epoxy resin and flame retardant additives on thermal properties of oil palm trunk particleboards were analysed by thermogravimetric analysis. The thermogravimetric diagram of samples is shown in figure 2, where the thermogravimetric curves exhibit three main weight loss stages. The initial stage from 100 to $250^{\circ} \mathrm{C}$, which is followed by a slight drop in weight, attributed to the evaporation of water and easily volatile materials, accompanied by thermal decomposition of hemicellulose, carbon dioxide and water [24] of samples at the second stage with the temperature ranging from 250 to $400^{\circ} \mathrm{C}$. Particleboard with epoxy resin and flame retardant additives resulted in a higher onset temperature of weight loss in the second stage than epoxy resin added particleboard and control particleboard. The increase in the onset degradation temperature is due to the inclusion of polar hydroxyl and carbonyl groups which leads to an increase in the bonding strength between resin and fibre chains with inorganic hydroxides which act as barriers; consequently more energy is needed for degradation. The final degradation stage
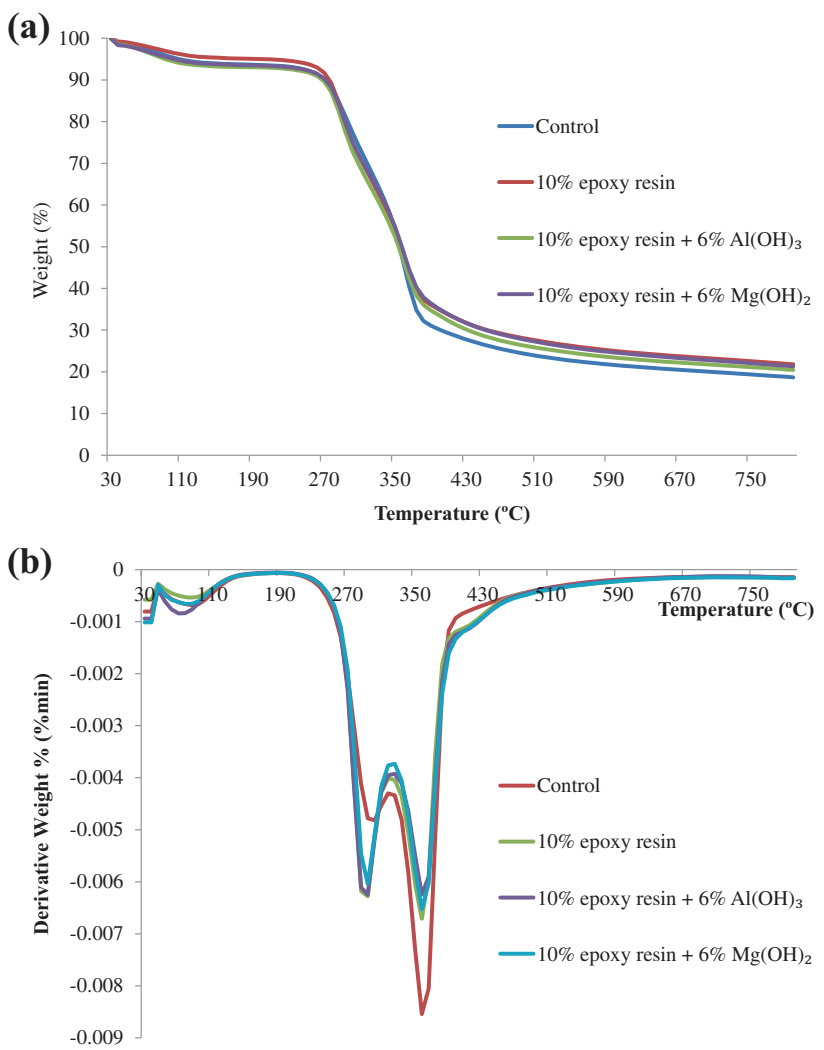

Figure 2. (a) Thermogravimetric and (b) derivative thermogravimetric curves of oil palm trunk particleboards. 
is attributed to ash formation where the samples decompose almost completely. Control particleboard had the lowest onset temperature at each stage which indicates that it is unable to withstand high temperature or possess weak thermal stability. From figure 2, it can be concluded that addition of flame retardant additives, namely aluminium hydroxide and magnesium hydroxide, to epoxy resin added particleboard significantly improved the thermal stability.

\subsection{Evaluation of functional group}

The functional group was analysed by Fourier transform infrared (FTIR) spectroscopy to observe differences between control particleboards and the manufactured particleboards with addition of epoxy resin and $6 \%$ of inorganic hydroxides. The FTIR spectra in figure 3 show the absorbance of the samples at various wavenumbers. The functional groups of

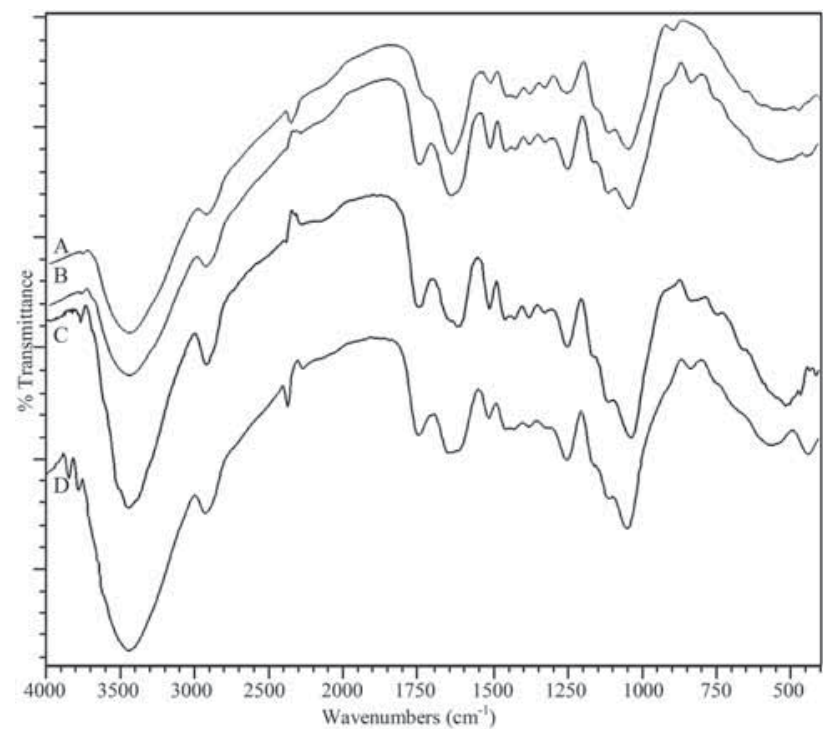

Figure 3. FTIR spectra of oil palm trunk particleboards. (A) Control board, (B) board with 10\% epoxy resin, (C) board with $10 \%$ epoxy resin $+6 \% \mathrm{Al}(\mathrm{OH})_{3}$ and (D) board with $10 \%$ epoxy resin $+6 \% \mathrm{Mg}(\mathrm{OH})_{2}$. the board samples were almost the same, however there was minimal difference in the peaks of all the board samples. The possible reaction between oil palm fibre and epoxy resin is shown in figure 4.

Based on figure 3, the intensities of the absorption band at a peak from 3400 to $3500 \mathrm{~cm}^{-1}$ in the board samples were corresponding to the $\mathrm{OH}$ stretching. The intensity of this peak becomes higher with addition of epoxy resin and flame retardant additives which indicates the presence of more $\mathrm{OH}$ stretching. A peak at $2900 \mathrm{~cm}^{-1}$ showed the presence of $\mathrm{C}=\mathrm{O}$ vibrating bands of the carboxylic group in hemicellulose [5]. There is a significantly different peak at around $1755 \mathrm{~cm}^{-1}$ which indicated the presence of the $\mathrm{C}=\mathrm{O}$ stretching absorption band contributed by the carbonyl group of epoxy resin while the peak at around $1650 \mathrm{~cm}^{-1}$ indicates the stretching of $\mathrm{C}=\mathrm{O}$ in the amide group [25]. Particleboards with epoxy resin and flame retardant additives exhibit a sharp peak at $1250 \mathrm{~cm}^{-1}$ which indicates the presence of aromatic ether from epoxy resin in the samples [26], while a peak around $1400 \mathrm{~cm}^{-1}$ denotes the presence of hemicellulose and arabinoxylan [25].

\subsection{Evaluation of crystalline properties}

X-ray diffraction (XRD) analysis was conducted to evaluate the crystallinity of the oil palm trunk particleboards with and without additions of epoxy resin and flame retardant additives. Figure 5 shows the diffraction patterns obtained for control, epoxy resin added, epoxy resin and aluminium hydroxide added and epoxy resin and magnesium hydroxide added particleboard. It exhibited a major peak intensity around $2 \theta=16^{\circ}$ and a secondary peak around $2 \theta=22^{\circ}$.

The crystallinity index was determined according to Segal et al [27] for all the oil palm trunk particleboards and the results are summarized in table 3. Control particleboard has the highest crystallinity index and it decreased slightly with additions of epoxy resin and flame retardant additives. This observation might be due to the existence of flame retardant additives which deposited only on the surface of fibres and

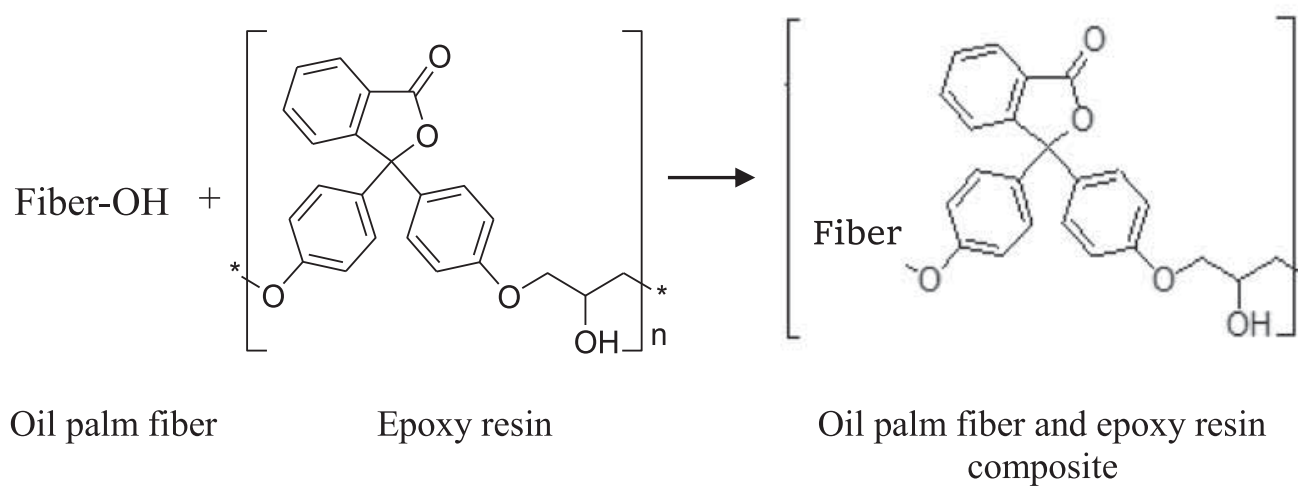

Figure 4. Possible reaction between oil palm fibre and epoxy resin. 


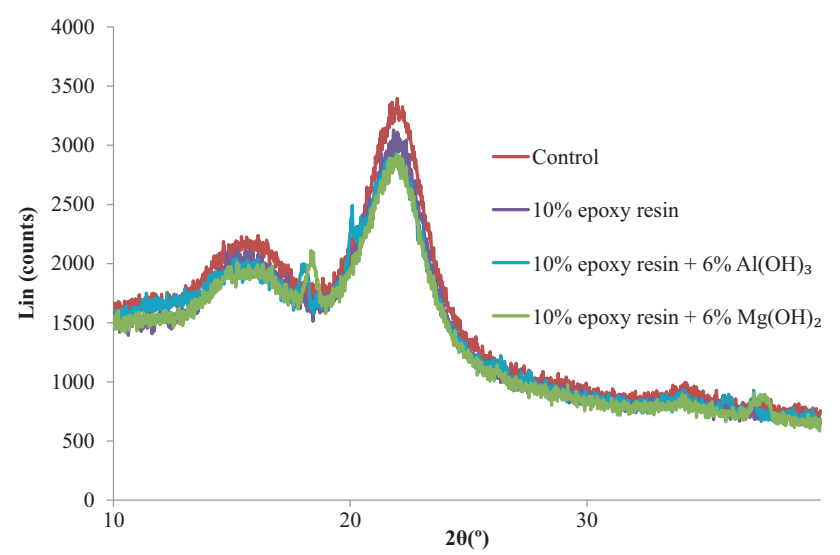

Figure 5. XRD patterns of the oil palm trunk particleboards. did not affect the crystalline region of the oil palm fibres. This statement is supported by the SEM observation in section 3.7.

\subsection{Evaluation of morphological properties}

Figure 6 illustrates the scanning electron microscopy (SEM) micrograph of control particleboard and the particleboard

Table 3. Crystallinity indices of the oil palm trunk particleboards.

\begin{tabular}{lc} 
Types of boards & Crystallinity (\%) \\
\hline Control & 34.11 \\
$10 \%$ epoxy resin & 32.68 \\
$10 \%$ epoxy resin $+6 \% \mathrm{Al}(\mathrm{OH})_{3}$ & 30.47 \\
$10 \%$ epoxy resin $+6 \% \mathrm{Mg}(\mathrm{OH})_{2}$ & 31.49 \\
\hline
\end{tabular}

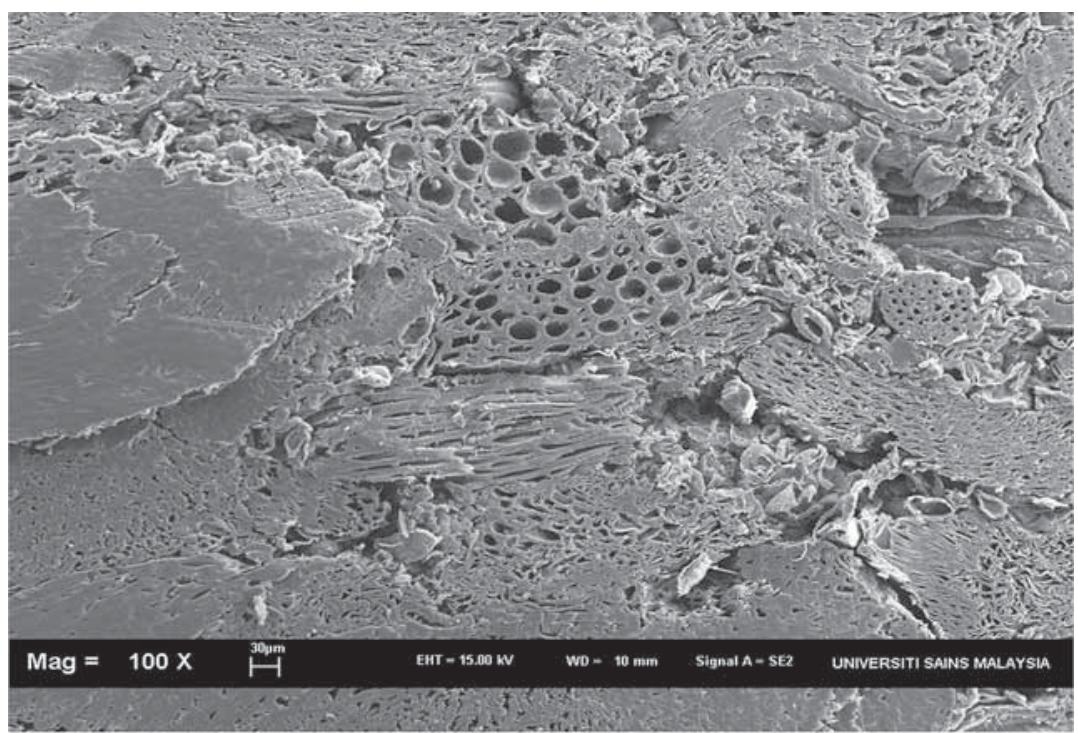

(a)

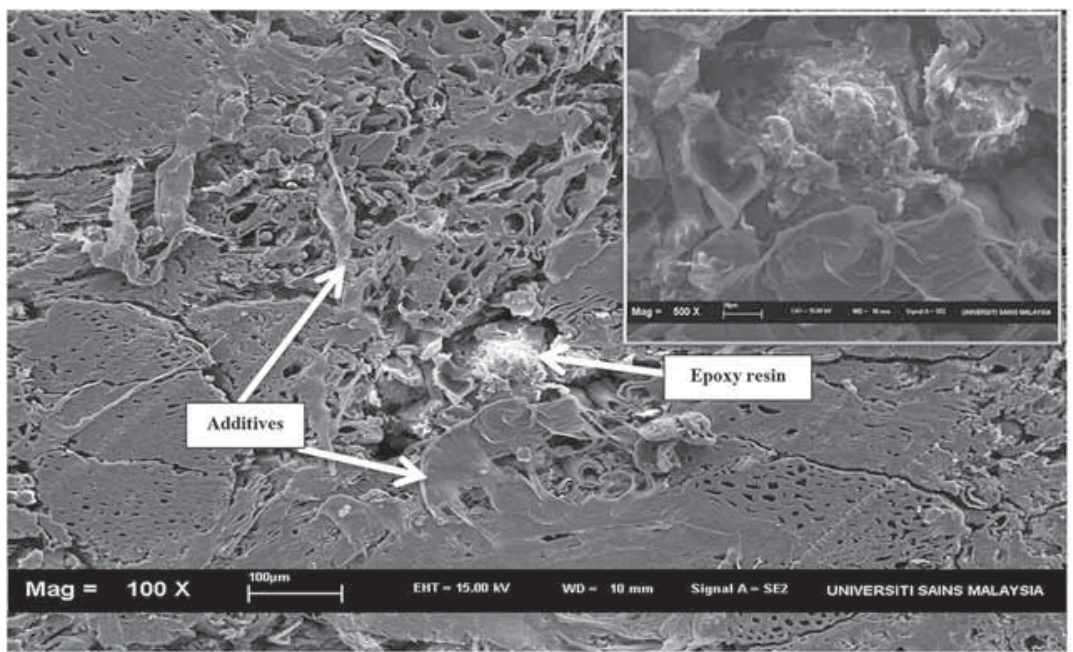

(b)

Figure 6. SEM micrograph showing the cross section view of (a) control particleboard and (b) particleboard with epoxy resin and flame retardant additives made from oil palm trunk. 


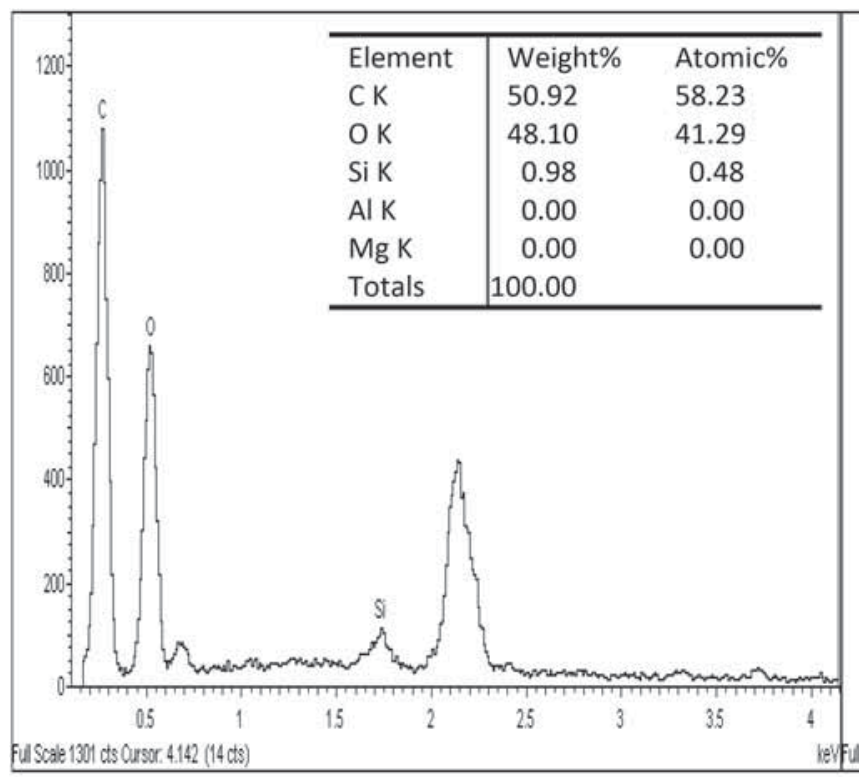

(a) Control particleboard

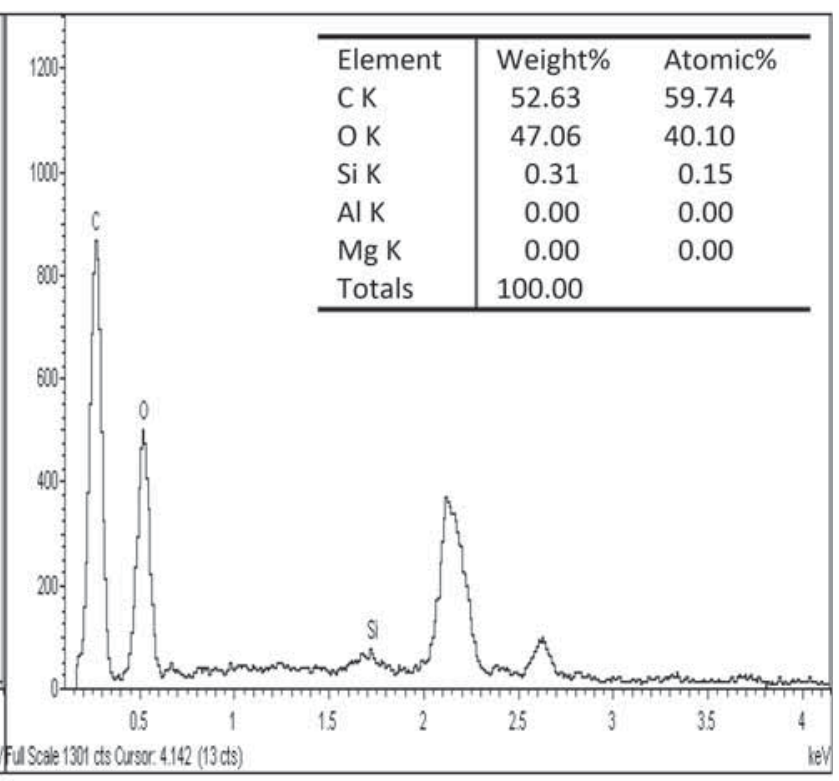

(b) Particleboard with $10 \%$ of epoxy resin

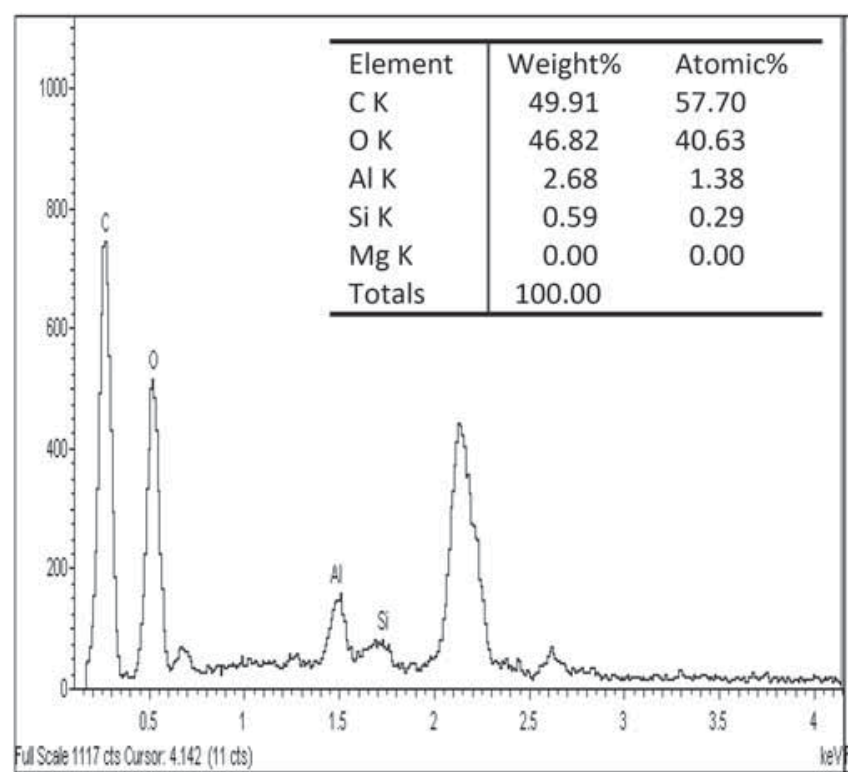

(c) Particleboard with $10 \%$ of epoxy resin and $6 \%$ aluminium hydroxide

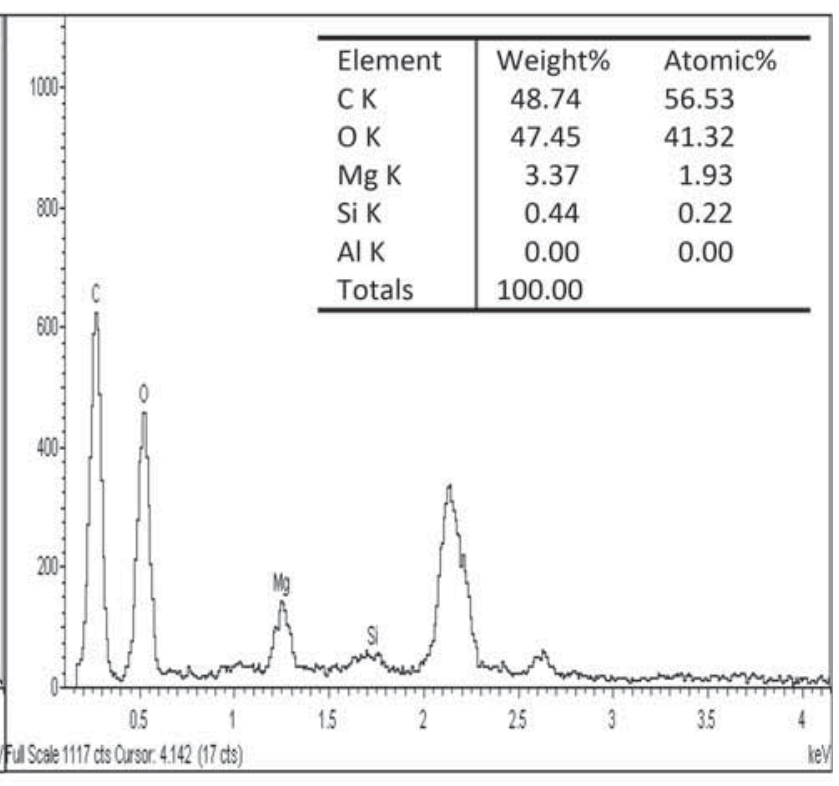

(d) Particleboard with $10 \%$ of epoxy resin and $6 \%$ magnesium hydroxide

Figure 7. EDXA spectra of cross-section of oil palm trunk particleboard with their elemental compositions.

sample with $10 \%$ epoxy resin and $6 \%$ flame retardant additives. Figure 6a clearly illustrates the compressed cell walls, fibres and parenchyma ground tissue due to the pressing method during manufacturing of particleboard and even a small amount of silica was detected. These cells provide good bonding between the fibres and improve the interfacial adhesion as no adhesive was used when producing the control board. A granule like substance found on the cell wall of fibre represents the epoxy resin which acted as a binder as shown in figure 6b. It also showed that aluminium hydroxide and magnesium hydroxide act as flame retardant additives well dispersed and deposited on the surface of fibres and parenchymatic cells.

\subsection{Evaluation of elemental composition properties}

Figure 7 shows the elemental composition present in the oil palm trunk particleboards analysed by a SEM with 
energy dispersive X-ray analysis (EDXA). Carbon, oxygen and silica contents were detected in all oil palm trunk particleboards. A small increase in the carbon percentage of epoxy resin added particleboard compared to control particleboard was due to the loss of some volatile nitrogen, chlorine, potassium and oxygen compounds during hot pressing [28], while the oxygen content by weight percentage of all samples was almost the same. Control board had the highest silica content because it does not contain any resin and flame retardant chemicals that will alter its cell wall structure. The presence of aluminium as shown in figure $7 \mathrm{c}$ and magnesium as shown in figure $7 \mathrm{~d}$ is in agreement with the presence of small granules shown in figure $6 b$.

\section{Conclusions}

The properties of control particleboard, particleboard with addition of $10 \%$ epoxy resin and particleboard with addition of $10 \%$ epoxy resin and $6 \%$ flame retardant additives, namely aluminium hydroxide and magnesium hydroxide, were investigated. Based on the result, epoxy resin was found to be a potential binder as it improved physical and mechanical properties of oil palm trunk particleboard. Besides, the mechanical properties of all types of boards have met the minimum requirement of Japanese Industrial Standard for Type 8. Particleboard with 10\% epoxy resin and aluminium hydroxide or magnesium hydroxide showed a significant improvement in flame retardant and thermal stability properties. The results indicated that particleboard with epoxy resin and flame retardant additives had improved mechanical, physical, thermal and flame retardant properties compared to control oil palm trunk particleboard. Overall results showed that epoxy resin as a function of a binder and aluminium hydroxide and magnesium hydroxide as a function of additives have the potential to be incorporated into particleboard to improve flame retardant properties.

\section{Acknowledgements}

The authors express their gratitude to the Ministry of Higher Education Malaysia for MyBrain15 scholarship to Mohana Baskaran. We acknowledge University RU Grant 1001/PTEKIND/814256. Assistance in raw materials supplied by Encore Agricultural Industries Sdn Bhd, Kuala Lumpur is also acknowledged.

\section{References}

[1] Sulaiman O, Salim N, Nordin N A, Hashim R, Ibrahim M and Sato M 2012 BioResources 72688

[2] Statistics: Oil Palm Planted Area. http://bepi.mpob.gov.my (accessed 23 September 2017)

[3] Sumathi S, Chai S P and Mohamed A R 2008 Renew. Sustain. Energy Rev. 122404

[4] Agensi Inovasi Malaysia 2013 National Biomass Strategy 2020: New wealth creation for Malaysia's palm oil industry

[5] Ahmad N, Kasim J, Mahmud S Z, Yamani S A K, Mokhtar A and Yunus N Y M 2011 3rd Int. Symp. \& Exhibition on Sustainable Energy \& Environment (ISESEE) p 84

[6] Halvarsson S, Edlund H and Norgren M 2009 Ind. Crops Prod. 29437

[7] Hashim R, Nadhari W N A W, Sulaiman O, Hiziroglu S, Sato M, Kawamura F et al 2011 J. Compos. Mater. 451659

[8] Hashim R, Nadhari W N A W, Sulaiman O, Sato M, Hiziroglu S, Kawamura F et al 2012 BioResources 71352

[9] Pedieu R, Koubaa A, Riedl B, Wang X M and Deng J 2012 Eur. J. Wood Wood Prod. 70191

[10] Toldy A, Szabó A, Novák C, Madarász J, Tóth A and Marosi G 2008 Polym. Degrad. Stab. 932007

[11] Laks P E and Palardy R D 1990 Proc. of First Int. Conf. on Wood Protection with Diffusible Preservatives $\mathrm{p} 76$

[12] Mun C K, Yhaya M F and Azahari B 2016 Imp. J. Interdiscip. Res. 21557

[13] Lo E S 1960 Ind. Eng. Chem. 52319

[14] Baskaran M, Hashim R, Sulaiman O, Awalludin M F, Sudesh K, Arai T et al 2017 Waste Biomass Valor. 10179

[15] Japanese Industrial Standards A 5908-2003

[16] BS2782-1 1986 ISO 4589-1984

[17] Garea S A, Corbu A C, Deleanu C and Iovu H 2006 Polym. Test. 25107

[18] Pandey S and Gurjar R 1987 Biol. Wastes 19197

[19] Halligan A F 1970 Wood Sci. Technol. 4301

[20] Sauter S 1996 Proc. of the 30th Int. Particleboard/Composite Material Symposium WSU p 197

[21] Mo X, Cheng E, Wang D and Sun X S 2003 Ind. Crops Prod. 18 47

[22] Lu S Y and Hamerton I 2002 Prog. Polym. Sci. 271661

[23] Morose G 2006 PhD Thesis (University of Massachusetts, Lowell)

[24] Baskaran M, Hashim R, Sudesh K, Sulaiman O, Hiziroglu S, Arai T et al 2015 Ind. Crops Prod. 51334

[25] Peng F, Ren J L, Xu F, Bian J, Peng P and Sun R C 2009 J. Agric. Food Chem. 576305

[26] Meure S, Wu D Y and Furman S A 2010 Vib. Spectrosc. 52 10

[27] Segal L, Creely J, Martin A and Conrad C 1959 Text. Res. J. 29 786

[28] Nadhari W N A W, Hashim R, Sulaiman O, Sato M, Sugimoto T and Selamat M E 2013 BioResources 81675 